\title{
Pilot Study Analysis of Three Different Processes in Drinking Water Treatment
}

\author{
Dae Ho Kim, Byoung Ho Lee ${ }^{\dagger}$ \\ Civil and Environmental Engineering, University of Ulsan
}

\begin{abstract}
In this study, three pilot-scale plants with the capacity $30 \mathrm{~m}^{3} /$ day were designed and set up to treat reservoir water for the production of drinking water. Three treatment processes were compared in the pilot testing: process 1 (coagulation- flocculation- sedimentationsand filtration- ozone- BAC); process 2 (coagulation- flocculation- sedimentation- microfiltration-ozone- BAC); and process 3 (coagulation- flocculation- sedimentation- sand filtration- GAC). The quality of water has been evaluated on the basis of selected parameters such as turbidity, color, consumption of $\mathrm{KMnO}_{4}$, dissolved organic carbon (DOC), trihalomethane formation potential (THMFP), geosmin and 2-MIB. A detailed assessment of performance was carried out during a five months operation. Process 2 was found to have better removal efficiency of DOC, THMFP, geosmin and 2-MIB than process 1 and process 3 under identical conditions, although the removal rate of color was found to be the same in the three cases.
\end{abstract}

Keywords: Activated carbon, Drinking water, Microfiltration, Ozonation, Sand filtration

\section{Introduction}

Drinking water is normarlly produced by removing various compounds in natural surface water. Due to the serious pollution of surface water and stricter drinking water standards, drinking water quality from the conventional treatment process may not be at a satisfactory level. Membrane technology has been considered as a substitute for conventional drinking water treatment for effective retention of particulates, bacteria, and some viruses $[1,2]$. In particular, microfiltration (MF) and ultrafiltration (UF) technologies are receiving more attention than the Reverse Osmosis (RO) system due to their lower energy consumption, and their economic and easy operation [3,4]. Ozone is one of the most effective oxidants and disinfectants for drinking water production. Moreover, it can strongly oxidize saturated and unsaturated bonds in organic compounds. It has many other benefits such as the removal of natural and synthetic organic compounds (i.e., taste and odor compounds, and pesticides), the avoidance of halogenated disinfection-by-products (DBPs) formation, and improved flocculation by preozonation [5].

The activated carbon adsorption process has been applied to remove DBPs. Before the granular activated carbon process, ozone was applied to oxidize refractory organic matter, which increased the biodegradability of substances. The GAC bed adsorbs small organic compounds and DBPs following the ozonization process $[5,6]$. GAC has a large interfacial area that adsorbs compounds associated with chlorinated compounds
(Trihalomethanes, THMs, and Haloacetic Acids, HAAs ), phenolic compounds, dyes, toxic metals and substances which cause biological after growth [7].

The Cheon-Sang water treatment plant (Ulsan, Korea) is the supplier of drinking water for the Ulsan area, of which the population is over 1 million. The raw water of the Cheon-Sang water treatment plant is drawn from a nearby reservoir. The water is polluted due to the discharge of agricultural and industrial wastewater in the intake area of the reservoir, which is currently in the eutrophication process. Currently, the Cheong-San water treatment plant employed conventional treatment processes, including prechlorination, coagulation, sedimentation, rapid sand filtration, and disinfection. The conventional treatment processes could not completely remove the contaminants concerned. In order to search suitable treatment processes to upgrade the exiting facilities, a pilot plant was built in the Cheon-Sang water treatment plant. The performance of these treatment processes were compared on the basis of seletcted parameters such as turbidity, alkalinity, color, consumption of $\mathrm{KMnO}_{4}$, dissolved organic carbon (DOC), trihalomethane formation potential (THMFP), geosmine, and MIB.

\section{Materials and Methods}

\subsection{Pilot Plant}

Received October 24, 2010 Accepted December 02, 2011

${ }^{\dagger}$ Corresponding Author

E-mail: bhlee@ulsan.ac.kr

Tel: +82-10-5459-0500 Fax: +82-52-259-2629 


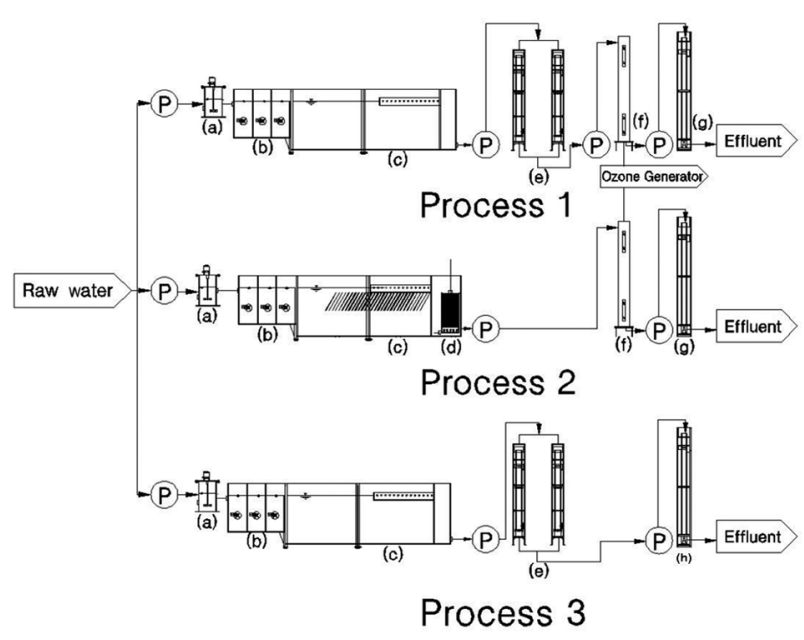

Fig.1. Schematic diagram of the pilot plant in (a) coagulation, (b) flocculation, (c) sedimentation, (d) membrane filtration, (e) sand filtration, (f) ozonation, (g) BAC, and (h) GAC.

The pilot scale plant was set up at the Cheon-Sang water treatment plant. Three treatment processes were operated in this test and the performance assessment of the pilot plant was carried out over the five months. Fig. 1 shows the schematic diagram of the pilot plant used in this study. The raw water used in this treatment was taken from a nearby reservoir, and was divided into three processes: coagulation- flocculation- sedimentation- sand filtration- ozone- BAC (process 1); coagulation- flocculationsedimentation-membrane filtration-ozone- BAC (process 2); and coagulation- flocculation- sedimentation- sand filtrationGAC (process 3 ). The flow rate of the influent for each process was $30 \mathrm{~m}^{3}$ /day. Polyaluminum chloride (PACl) was diluted by 20 times and was used as a coagulant, and the feed flow rate was $2.5 \mathrm{~mL} / \mathrm{min}$. Flocculation was performed with a volume and detention time of $0.76 \mathrm{~m}^{3}$ and $36.41 \mathrm{~min}$, respectively. The depth of the gravel layer was $300 \mathrm{~mm}$, and that of the sand (effective size of $0.45-0.7 \mathrm{~mm}$ ) layer was $1,100 \mathrm{~mm}$ in the sand filter bed of processes 1 and 3. Backwashing of the sand filter was carried out every other day and GAC column backwashing was also performed twice a week. The MF membrane used in process 2 was produced by KOLON, Korea, with a membrane surface area of 20 $\mathrm{m}^{2}$, and a pore size of $0.1 \mu \mathrm{m}$ (Cleanfil-S20HP). The membrane was operated at the feed flow rate of $20.83 \mathrm{~L} / \mathrm{min}$, a permeate flow rate of $18.75 \mathrm{~L} / \mathrm{min}$, and a trans-membrane pressure of 0.03 $\mathrm{MPa}$. Backwashing and chemical cleaning of MF was carried out regularly for preventing fouling. The GAC column of each process was filled to a 2,500 mm height (Shin Ki Chemicals, Yangsan, Korea ) with an empty bed contact time (EBCT) of $4.3 \mathrm{~min}$.

The ozone generator (WEDECO Series GSO/SWO 2088; Xylem Water Solution, Herford, Germany) was operated with a flow rate of $0.5-3 \mathrm{mg} / \mathrm{L}$. The flow rate of raw water was $20.83 \mathrm{~L} / \mathrm{min}$. Thus, the entire capacity of the pilot plant was about $90 \mathrm{~m}^{3} /$ day.

\subsection{Analysis}

Raw water and permeate samples from each process were collected every week. Samples were taken simultaneously from all the processes. $\mathrm{pH}$ and temperature were measured using a pH meter (Horiba D51; Horiba Ltd., Kyoto, Japan). Turbidity was measured using a portable analyzer (Hach 2001AN; Hach, Loveland, CO, USA). These parameters were measured at the sampling sites. Samples including a raw water sample were carried to the laboratory, pre-filtered with a $0.45 \mu \mathrm{m}$ filter to remove particles, and stored in a refrigerator at $4{ }^{\circ} \mathrm{C}$ for the analysis. The alkalinity, color, and $\mathrm{KMnO}_{4}$ were measured according to the standard methods [8].

DOC concentrations were analyzed by the Non-purgeable Organic Carbon (NPOC) method using a Total Organic Carbon (TOC) analyzer (Sievers 5310C; General Electric Co., Boulder, CO, USA). UV254 absorbance was measured with a Shimadzu UV-1240 ultraviolet-visible (UV/VIS) spectrophotometer (Shimadzu, Tokyo, Japan). Mn was measured using Inductive Coupled Plasma-Mass Spectrometry (ICP-MS 7500; Agilent, Santa Clara, CA, USA).

Concentrations of THMs were analyzed using a head space method using a gas chromatograph $(6890 \mathrm{~N}$, Agilent) coupled with a micro-electron capture detector (ECD). The make-up gas used was high purity nitrogen, and the specification of the capillary column was $30.0 \mathrm{~m} \times 0.53 \mathrm{~mm}$ I.D. $\times 3.0 \mathrm{~m}$ (DB-1, Agilent). In the THMFP measured process, NaClO (Hanwha, Seoul, Korea) was used as the disinfection agent. Calibration curves were constructed prior to the analysis of THMs with different diluted standard solutions of $\mathrm{CHCl}_{3}, \mathrm{CHCl}_{2} \mathrm{Br}, \mathrm{CHClBr}_{2}$, and $\mathrm{CHBr}_{3}$. MIB and geosmin analyses were conducted using solid phase microextraction and gas chromatography-mass spectrometry [8].

\section{Results and Discussion}

\subsection{Water Characteristics}

Table 1 shows the raw water quality characteristics in this study. Raw water was taken from a nearby lake. A relatively fair water quality was maintained because there are not many pollution sources in the uptake area of the lake. The temperature was moderate during the experiment. TOC levels were within an average range over the year.

\subsection{Turbidity and Alkalinity}

Fig. 2 shows the turbidity concentrations of the raw water and finished water from various processes. The average value of turbidity is presented in Table 2. Finished water from process 1 achieved the lowest average turbidity ( $0.11 \mathrm{NTU})$ as well as the least measurement variation. Process 2 treated water had a slightly higher turbidity ( 0.115 NTU) than that of process 1 . The average turbidity of process 3 was 0.12 NTU, and its measurement variations became larger at the same time. Due to enhancement of coagulation performance by ozone oxidation,

Table 1. Characteristics of raw water quality

\begin{tabular}{lcc}
\hline Parameters & Measured range & Average \\
\hline Temperature $\left({ }^{\circ} \mathrm{C}\right)$ & $18.4-20.8$ & 22.2 \\
$\mathrm{pH}$ & $7.28-7.43$ & 7.29 \\
$\mathrm{UV} 254\left(\mathrm{~cm}^{-1}\right)$ & $0.057-0.065$ & 0.065 \\
$\mathrm{TOC}(\mathrm{mg} / \mathrm{L})$ & $2.86-3.67$ & 3.401 \\
$\mathrm{Mn}(\mathrm{mg} / \mathrm{L})$ & $0.02-0.16$ & 0.169 \\
\hline
\end{tabular}

TOC: Total Organic Carbon 


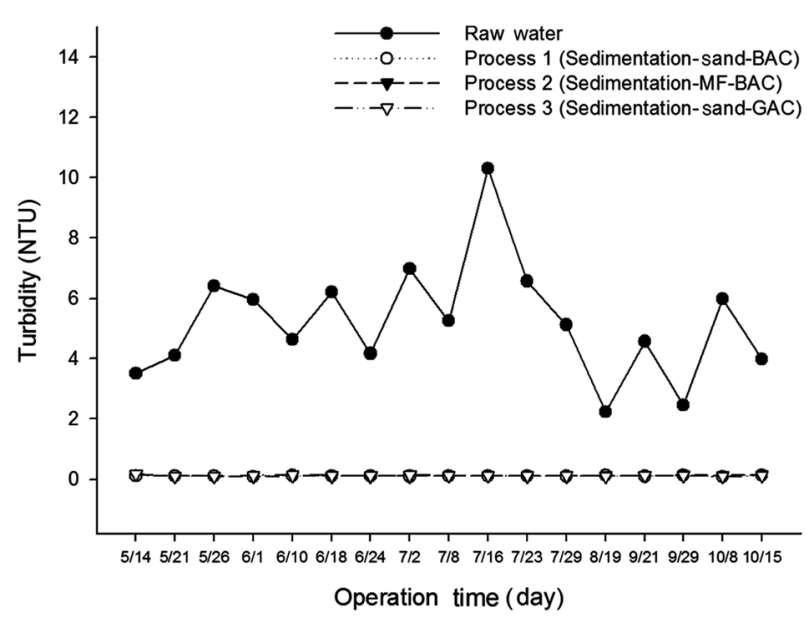

Fig. 2. Turbidities in different treatment processes and raw water.

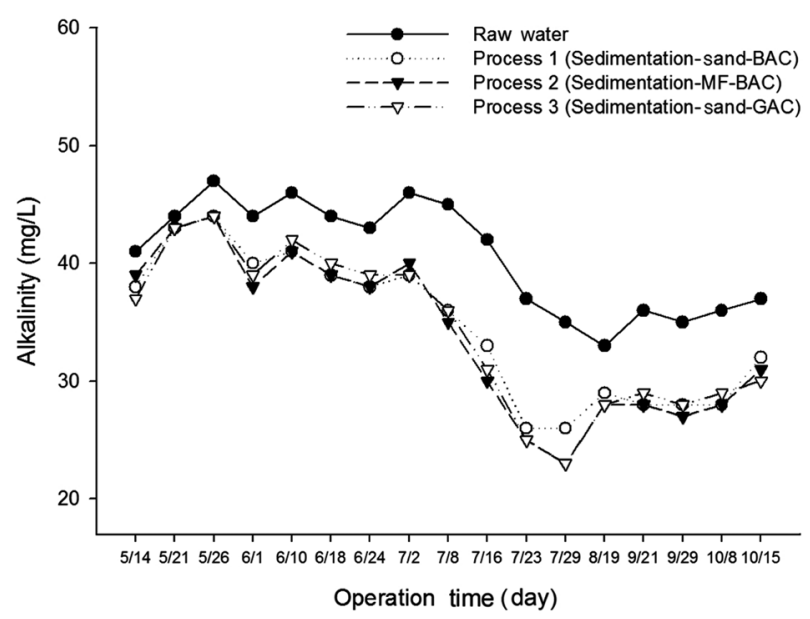

Fig. 3. Alkalinities in raw water and various treatment processes.

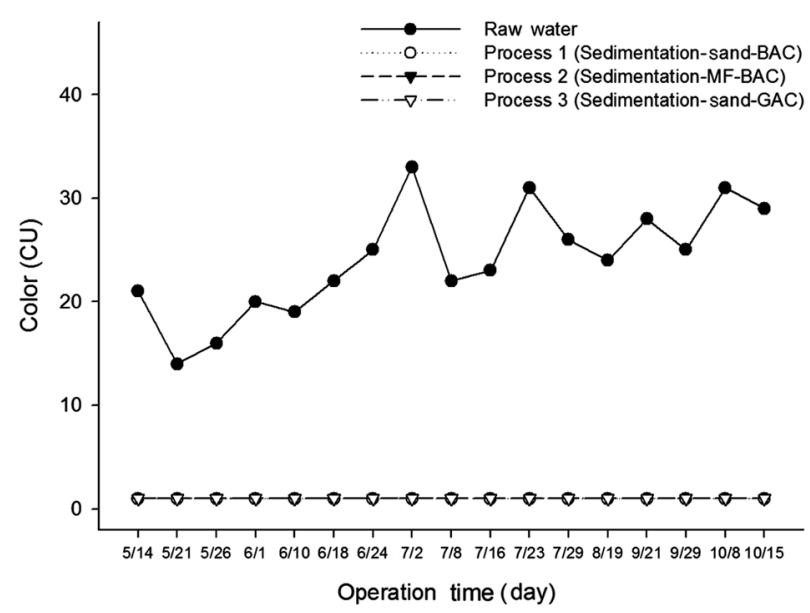

Fig. 4. Colors in processes 1, 2, 3 and raw water. process 1 and process 2 showed somewhat higher removal rates of turbidity than those of process 3 . Even though turbidity removal efficiency was shown to be the best in process 1 , the differences between the processes are within measurement error.

The average alkalinity of the water from various treatment processes is shown in Table 2 and its measured concentration is shown in Fig. 3. The alkalinity of treated water from process 2 was $33.9 \mathrm{mg} / \mathrm{L}$, whereas the alkalinity in process 3 was slightly higher than that from process 2 . The alkalinity of the treated water of process 1 was $34.6 \mathrm{mg} / \mathrm{L}$ on average. Alkalinity was sufficiently maintained to keep the $\mathrm{pH}$ within the range of good coagulation in all processes.

\subsection{Color and $\mathrm{KMnO}_{4}$}

Natural color is classified as a secondary contaminant of potable water, although there is no record that the color of water is harmful to human health [9]. However, the problem with color is the loss of public confidence in the quality of potable water. The recommended limit of natural color in drinking water is 1 [10].

Fig. 4 shows the measured value of color according to the three treatment processes. It can be seen from the figure that the color of raw water ranged from 21 to $29 \mathrm{CU}$ with an average value of $24 \mathrm{CU}$. Color was $1 \mathrm{CU}$ with a removal efficiency of $98 \%$ after the treatment of process 1 , process 2 , and process 3 . Natural color of the lake water may be sufficiently removed to gain the drinking water quality standard by coagulation and flocculation, sedimentation, and sand filtration or microfiltration even without ozonation.

The presence of oxidizable organics or inorganics in water reduces disinfection effectiveness. As a surrogate parameter, permanganate is measured because permanganate will be consumed in the oxidation of organics and inorganics. Permanganate oxidizes a wide variety of inorganic and organic substances in the $\mathrm{pH}$ range of 4 to 9 . Under typical water conditions, iron and manganese are oxidized and precipitated, and most contaminants that cause odors and tastes, such as phenols and algal organic matter, are readily degraded by permanganate [9]. In this study, $\mathrm{KMnO}_{4}$ was used as an oxidant to check the consumption rate for removal of these materials. Fig. 5 shows the consumption rate of $\mathrm{KMnO}_{4}$. Consumption of $\mathrm{KMnO}_{4}$ in processes 1, 2, and 3 was $1.63,1.23$, and $2.17 \mathrm{mg} / \mathrm{L}$, respectively (Table 2 ). The lowest value in process 2 indicates that a lower amount of $\mathrm{KMnO}_{4}$ was required for oxidation of organic and inorganic materials present in water. Process 1 and process 2 showed higher $\mathrm{KMnO}_{4}$ removal rates than process 3 because process 1 and process 2 used

Table 2. Average water qualities of raw water and finished water from various processes

\begin{tabular}{lcccc}
\hline Parameters & Raw water & Process 1 & Process 2 & Process 3 \\
\hline Color $(\mathrm{CU})$ & 24 & 1 & 1 & 1 \\
$\mathrm{KMnO}_{4}(\mathrm{mg} / \mathrm{L})$ & 8.41 & 1.63 & 1.23 & 2.17 \\
$\mathrm{DOC}(\mathrm{mg} / \mathrm{L})$ & 3.1 & 1.29 & 1.23 & 1.66 \\
$\mathrm{THMFP}(\mathrm{mg} / \mathrm{L})$ & 0.17 & 0.05 & 0.04 & 0.07 \\
Turbidity $(\mathrm{NTU})$ & 5.20 & 0.11 & 0.115 & 0.121 \\
Alkalinity & 40.6 & 34.6 & 33.9 & 34.2 \\
\hline
\end{tabular}

DOC: dissolved organic carbon, THMFP: trihalomethane formation potential. 


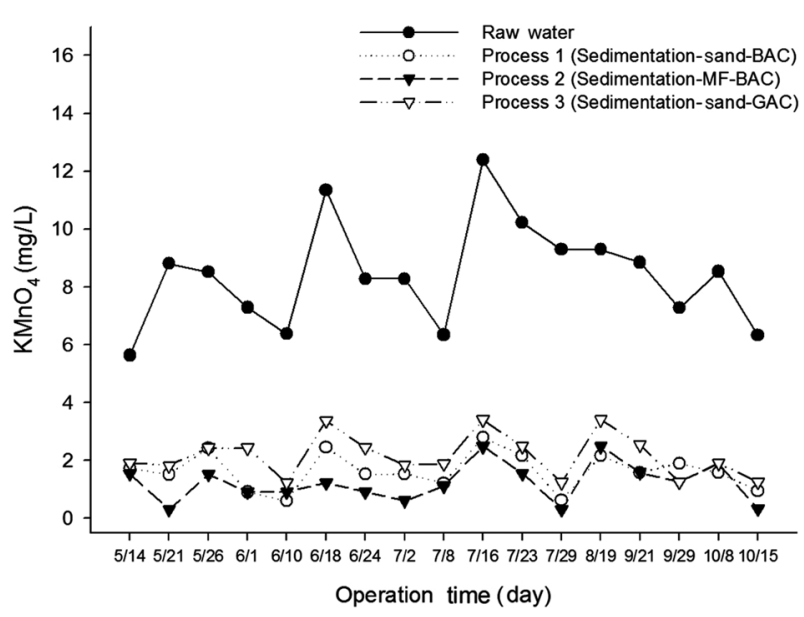

Fig. 5. Consumed $\mathrm{KMnO}_{4}$ concentrations in various treatment processes and raw water.

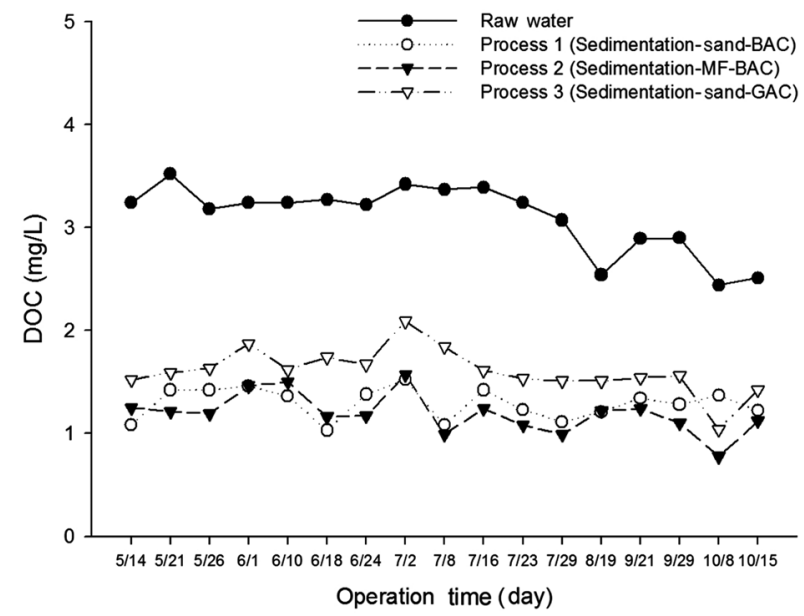

Fig. 6. DOC concentrations in raw water, processes 1,2 , and 3 .

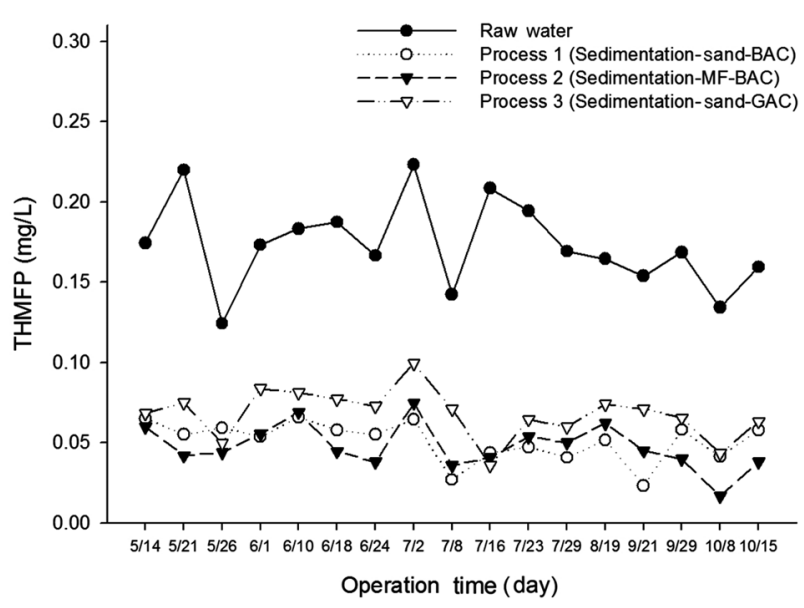

Fig. 7. Trihalomethane formation potential (THMFP) concentrations in processes 1, 2, 3 and raw water. ozonation while process 3 did not, which indicates that ozone reduced the $\mathrm{KMnO}_{4}$ consumption potential in treated water.

\subsection{DOC and THMFP}

DOC is commonly used as a parameter for the formation potential of DBPs, as some organic compounds in natural waters form DBPs. The DOC variation of the raw water and treated water from three treatment processes are shown in Fig. 6 . The DOC values of raw water ranged from 2.51 to $3.24 \mathrm{mg} / \mathrm{L}$, with an average of $3.1 \mathrm{mg} / \mathrm{L}$. The average value of DOC for treated water for processes 1, 2, and 3 was 1.29, 1.23, and $1.66 \mathrm{mg} / \mathrm{L}$, respectively (Table 2). It was observed that up to $61 \%$ reduction of DOC was found for treatment process 2 , followed by treatment process 1 with a removal efficiency of $58 \%$. Process 3 had the lowest removal rate of DOC (47\%). This may be attributed to the fact that the incorporation of microfiltration with GAC in process 2 retains higher molecular weight organic compounds from water than in the sand filtration of process 1 . The removal efficiency was low due to the absence of the ozonation process in process 3 . The results demonstrate that ozone oxidizes DOC material in water. Also, the straining effect of the DOC material of process 2 is higher in the membrane than in the sand bed.

The possible production of THM by Dissolved Organic Matter (DOM ) with chlorine was assessed in terms of THMFP. Fig. 7 shows the measurement variation of the THMFP obtained from treated waters and raw water from processes 1,2 , and 3 . The THMFP of raw water ranged from 0.13 to $0.17 \mathrm{mg} / \mathrm{L}$, with an average value of $0.17 \mathrm{mg} / \mathrm{L}$. It can be seen from Table 2 that the THMFP was lowered to $0.05 \mathrm{mg} / \mathrm{L}(70 \%)$ after treatment in process 1 , whereas in processes 2 and 3 it was reduced to $0.04 \mathrm{mg} / \mathrm{L}$ (77\%) and $0.07 \mathrm{mg} / \mathrm{L}$ (59\%), respectively. The low THMFP value implies a high THM precursor's removal efficiency in process 2 . Process 2, in which the membrane was incorporated, showed higher removal efficiency than any other treatment process. This implies that using a membrane system with GAC would reduce the humic contents in the filtrates, resulting in mitigation of the formation of DBPs in final chlorination. The removal efficiency of THMFP showed a similar pattern to that of DOC. It may be assumed that the ozone removed the THM precursors to some extent.

\subsection{Geosmin and 2-MIB}

Tastes and odors of drinking water have long been of concern as they account for many consumer complaints. MIB (2-methylisoborneol) and geosmin (trans-1, 10-dimethyl-trans-9-decalol) are two of the most common tastes and odors. Both compounds are volatile saturated tertiary alcohols and impart an earthy/ musty odor that can be detected at extremely low concentrations of between 10 and $20 \mathrm{ng} / \mathrm{L}$ [6, 11]. Neither MIB nor geosmin is readily removed by conventional water treatment, thus advanced treatment processes such as ozonation and activated carbon are required. Additional processes incorporating oxidation or adsorption are generally required to remove these dissolved organics including geosmin and MIB. Activated carbon has been shown to be an effective adsorbent for the removal of MIB and geosmin [12]. In this study, the raw water was spiked with $400 \mathrm{ng} / \mathrm{L}$ of geosmin and $200 \mathrm{ng} / \mathrm{L}$ of MIB for one hour. The movement of spiked water body through the units of the pilot plant was carefully calculated. Then, samples of each process were taken during the middle part of the passing period of spiked 
water body to minimize experimental error. The concentrations of the two samples are the limits which occur in early summer at the reservoir. Samples were taken in the finished water (GAC effluent) of the three processes at 20 and 40 minutes after the total retention period of each process. The total hydraulic retention time periods of the three processes are about 7 hours, 5 hours and 55 minutes, and 6 hours, respectively. The measured concentrations in finished waters from each process are presented in Tables 3 and 4. It can be seen from the table that as the ozone concentration increases, the concentrations of the two materials were not detected at higher ozone concentrations of 2 and $3 \mathrm{mg} / \mathrm{L}$ for processes 1 and 2 . It was observed under the comparable condition that the removals of geosmin and MIB were higher in process 2 than in processes 1 and 3. This may be due to the incorporation of membrane filtration in process 2 . The extremely low value of these compounds in processes 1 and 2 indicates that the incorporation of ozonation and activated carbon could enhance the removal of these compounds. Process 3 without ozone application could not remove geosmin and MIB in the final finished water. It was also revealed that over $2 \mathrm{mg} / \mathrm{L}$ of ozone application with GAC could remove geosmin and MIB by about $100 \%$ even when they occur in the upper limits of concentrations of the two materials.

Table 3. Concentrations of geosmin in various processes at 20 and 40 minutes after the total retention periods

\begin{tabular}{lcccc}
\hline \multirow{2}{*}{$\begin{array}{c}\text { Treatment } \\
\text { processes }\end{array}$} & $\begin{array}{c}\text { Raw water } \\
(\mathbf{n g} / \mathrm{L})\end{array}$ & $\begin{array}{c}\text { Ozone } \\
\text { concentration } \\
(\mathbf{m g} / \mathrm{L})\end{array}$ & \multicolumn{2}{c}{$\begin{array}{c}\text { Finished water } \\
(\mathbf{n g} / \mathrm{L})\end{array}$} \\
\cline { 4 - 5 } & & & $\mathbf{2 0} \mathbf{m i n}$ & $\mathbf{4 0} \mathbf{~ m i n}$ \\
\hline Process 1 & 400 & 1 & 8.3 & 4.9 \\
& & 2 & $\mathrm{ND}$ & $\mathrm{ND}$ \\
& & 3 & $\mathrm{ND}$ & $\mathrm{ND}$ \\
Process 2 & \multirow{2}{*}{400} & 1 & 7.8 & 5.9 \\
& & 2 & $\mathrm{ND}$ & $\mathrm{ND}$ \\
& & 3 & $\mathrm{ND}$ & $\mathrm{ND}$ \\
Process 3 & \multirow{2}{*}{400} & - & 10.9 & 10.7 \\
& & - & 21.2 & 16.3 \\
& & - & 9.7 & 7.6 \\
\hline
\end{tabular}

ND: no data.

Table 4. Concentrations of MIB in processes 1, 2, and 3 at 20 and 40 min after the total retention periods

\begin{tabular}{|c|c|c|c|c|}
\hline \multirow{2}{*}{$\begin{array}{l}\text { Treatment } \\
\text { Processes }\end{array}$} & \multirow{2}{*}{$\begin{array}{c}\text { Raw water } \\
\text { (ng/L) }\end{array}$} & \multirow{2}{*}{$\begin{array}{c}\text { Ozone } \\
\text { concentration } \\
(\mathrm{mg} / \mathrm{L})\end{array}$} & \multicolumn{2}{|c|}{$\begin{array}{c}\text { Finished water } \\
\text { (ng/L) }\end{array}$} \\
\hline & & & $20 \mathrm{~min}$ & $40 \mathrm{~min}$ \\
\hline \multirow[t]{3}{*}{ Process 1} & 200 & 1 & 19.5 & 5.3 \\
\hline & & 2 & ND & ND \\
\hline & & 3 & ND & ND \\
\hline \multirow[t]{3}{*}{ Process 2} & 200 & 1 & 5.2 & ND \\
\hline & & 2 & ND & ND \\
\hline & & 3 & ND & ND \\
\hline \multirow[t]{3}{*}{ Process 3} & 200 & - & 12.5 & 9.9 \\
\hline & & - & 15.7 & 15.3 \\
\hline & & - & 12.9 & 9.8 \\
\hline
\end{tabular}

ND: no data.

\section{Conclusions}

Investigations have been performed to compare removal efficiencies on the basis of water quality parameters such as turbidity, alkalinity, color, $\mathrm{KMnO}_{4}$ consumption, DOC, THMFP, geosmin, and MIB in three different treatment processes. The highest removal efficiency of DOC, THMFP, geosmin, and MIB and lower consumption rate of $\mathrm{KMnO}_{4}$ was obtained in the coagulationflocculation-sedimentation-microfiltration-ozone-BAC process (process 1) than in the coagulation-flocculation-sedimentationsand filtration-ozone-BAC process (process 2) and in the coagulation-flocculation-sedimentation-sand filtration-GAC process (process 3 ) . Process 1 showed a slightly higher reduction rate in turbidity when compared with that in processes 2 and 3 . The removal efficiency of color was similar in the three applied treatment processes. Ozone might oxidize and break down the organic matter which was then removed more successfully by the microbial community in GAC. Thus, the removal rates of DOC and THMFP were higher in the ozonated treatment processes. The incorporation of microfiltration in process 2 was found to have higher removal efficiencies in most of the water quality parameters.

\section{References}

1. Bottino A, Capannelli C, Del Borghi A, Colombino M, Conio O. Water treatment for drinking purpose: ceramic microfiltration application. Desalination 2001;141:75-79.

2. Fiksdal L, Leiknes T. The effect of coagulation with MF/UF membrane filtration for the removal of virus in drinking water. J. Membr. Sci. 2006;279:364-371.

3. Kim HS, Takizawa S, Ohgaki S. Application of microfiltration systems coupled with powdered activated carbon to river water treatment. Desalination 2007;202:271-277.

4. Xia S, Li X, Zhang Q, Xu B, Li G. Ultrafiltration of surface water with coagulation pretreatment by streaming current control. Desalination 2007;204:351-358.

5. Bao ML, Griffini O, Santianni D, Barbieri K, Burrini D, Pantani F. Removal of bromate ion from water using granular activated carbon. Water Res. 1999;33:2959-2970.

6. Lalezary S, Pirbazari M, McGuire MJ. Evaluating activated carbons for removing low concentrations of taste- and odorproducing organics. J. Am. Water Works Assoc. 1986;78:76-82.

7. Zhao ZY, Gu JD, Fan XJ, Li HB. Molecular size distribution of dissolved organic matter in water of the Pearl River and trihalomethane formation characteristics with chlorine and chlorine dioxide treatments. J. Hazard. Mater. 2006;134:6066.

8. Eaton AD, Franson MA, American Public Health Association, American Water Works Association, Water Environment Federation. Standard methods for the examination of water and wastewater. 21st ed. Washington, DC: American Public Health Association; 2005.

9. Bryant EA, Fulton GP, Budd GC, Hazen and Sawyer. Disinfection alternatives for safe drinking water. New York: Van Nostrand Reinhold; 1992.

10. United States Environmental Protection Agency. Office of Water. Drinking water regulations and health advisories. Washington, DC: U.S. Environmental Protection Agency Office of Water; 1996.

11. Suffet IH, Corado A, Chou D, McGuire MJ, Butterworth S. 
AWWA: taste and odor survey. J. Am. Water Works Assoc. 1996;88:168-180.

12. Cook D, Newcombe G, Sztajnbok P. The application of powdered activated carbon for MIB and geosmin removal: predicting PAC doses in four raw waters. Water Res. 2001;35:1325-1333. 